\title{
Chickpea (garbanzos) Its' Nutritional and Economical Value
}

\author{
I. C. Gonzales, F. R. Gonzales, H. L. Quindara, P. L. Belino and E.T. Botangen, \\ Benguet State University La Trinidad, Benguet-2601 Philippines
}

\begin{abstract}
Chickpea locally known as garbanzos is being introduced in the Philippines to help reduce importation, improve nutritional problem and as alternative high value crop for the farmers and provide alternative health promoting food products in the market and alternative livelihood opportunities for entrepreneurs. ICCV 93952, ICCV 92311, ICCV 2, ICCV 94954, ICCV 95332, produced high yields and found to be productive under highlands conditions. Chickpea is a good source of minerals, protein and trace elements. Based on the results of the nutritional content of chickpea flour, it showed that it is high in dietary fiber, potassium, iron and sodium. Dietary fiber is essential for a healthy diet and for its ability to prevent or relieve constipation, lower risk of diabetes, heart disease, lower blood cholesterol, glucose levels and prevents colon cancer. Chickpea flour is three times higher in dietary fiber content than wheat flour and rice. Chickpea flour had low glycemic index and much lower than wheat flour and milled rice. Low glycemic index foods reduce blood sugar level thus prevent diabetes. Various products were developed with the supplementation wheat flour from chickpea flour. Thirty percent (30\%) substitution showed acceptable processed chickpea based food products which includes; eggdrop, cookies, bar, tart, buns, butter cake, leche flan, waffles, polvoron, etc. Chickpea in brine, in syrup, as fingerfood, as salad, as humus or paste were acceptable. Chickpea is a versatile food and could be prepared in several ways as salad, as humus/paste, and as processed product. It could combined with vegetables such as buridibud, apritada, as soup, as a drink or tea. To commercialize the product, production cost of each item was determined based on prevailing market price. Several trainings were also conducted, techno demo plots and hands on processing. Attendance and exhibition of the products to trade fairs were also actively participated in the Department of Science and Technology (DOST), Bureau of Agricultural Research-Department of Agriculture (DA-BAR), and Commission on Higher Education (CHED) and in the University anniversary celebrations.
\end{abstract}

Keywords: buns, desi-type, kabuli-type, garbanzos, leche flan

\section{Introduction}

At present, the supply of chickpea depends mainly on importation from India, Pakistan, Iran, Mexico, Australia and Canada. To help reduce importation, Chickpea production is being introduced in the Philippines. Initial results shows that the yield potential of $800-1200 \mathrm{~kg} / \mathrm{ha}$ is higher than the average global production of $700-800 \mathrm{~kg} / \mathrm{ha}$. Such findings imply that chickpea can be grown under Philippine conditions which can serve as an alternative high value crop for farmers.

Earlier findings (Gonzales 2010) showed that in the highlands of CAR, ICCV 93952 (Desi-type), ICCV 92311 (Kabuli type) produced the highest seed yield when planted at a planting distance of $30 \times 20 \mathrm{~cm}$ between rows and hills, applied with Sagana 100 at 5 tons $/ \mathrm{ha}(1 / 2 \mathrm{~kg} / \mathrm{m} 2)$ for organic farming, 45-100-45 kgs $\mathrm{NPK} /$ ha, weed free from sowing to first pod stage and was irrigated 15 days after seeding stage. Initial results showed that 2 cups wheat flour and one cup chickpea flour had the highest acceptability rating for cookies and puto (I. C. Gonzales and H.L. Quindara, 2009).

Chickpea is a good source of minerals, protein and trace elements. Legumes contain almost 2 times more protein and minerals and 3 times more in dietary fiber than wheat flour (Sath et. al, 1984). Legume proteins are rich in lysine which is an important essential amino acid limited in cereal grains (Muller, 1983). Its anti- nutritional factor is the lowest of all legumes.

In a technological feasibility of incorporating legume flours $(35 \%)$ for pasta making, nutritional analysis showed that the dough contains high levels of fiber, vitamin B1, magnesium, phosphorous, protein, good balance of essential amino acids. Its glycemic index is also lower than that of durum wheat dough. Lowered glyceamic index as a result adding legume flour is a positive characteristics of a wheat- legume food product. Utilization of the crop is limited to "igado" and halo- halo. Product development aims to explore alternative utilization techniques for the crop thereby increasing its product line in the market. Product development can promote production, utilization, and marketing of the crop.

This proposed project can help enhance alternative livelihood opportunities to farming households, reduce dollar drain and provide alternative nutritious and health promoting food products in the market. To developed food products that have low glyceamic index, low concentration of phytic acid and trypsin inhibitors and high vitamin content. Hence, the products will serve as alternative source of health promoting food products for the consumer market. 


\section{Activity 1. Development of chickpea based food products \\ II. Materials And Methods}

Chickpea grits/flour was processed before different products were developed. Nutritional content of chickpea flour was also analyzed at DOST -FNRI \& PIPAC . Chickpea flour was compared wheat flour and rice flour. Several products were developed and formulated such as eggdrop, lenguas, butter cookies, buns, eggdrop, tart, crackers, butter cake. Humus, fingerfood, salad, chickpea in syrup/brine, waffle, leche flan, polvuron and noodles etc. Chickpea seeds was also tasted as a beverage just like a hot coffee drink.

\section{Activity 2. Sensory evaluation of chickpea based food products developed}

Chickpea based food products which includes chickpea oatmeal bar, tart, cracker and buns were evaluated for its sensory characteristics. Sensory rating scale used was the 1-7 hedonic rating scale; 1-dislike very much, 2-dislike moderately; 3 dislike slightly; 4-neither like nor dislike, 5-like slightly, -like moderately, 7like very much.

Activity 3. Determine nutritional content and nutri-fact of chickpea substituted food products;

Chickpea flour was analyzed by DOST-FNRI and the nutria -facts of the different chickpea based food products was computed based on the 1997 Philippines Food Composition tables, FNRI-DOST.

\section{Activity 4. Costing of chickpea based food products develop}

Production cost of the different products were computed/ estimated based on the prevailing market price.

\section{Activity 5. Conduct of trainings/IEC materials production/Product exhibition}

Inorder to popularize and promote the utilization of chickpea based food products trainings/harvest/cooking festival were conducted at Loo, Buguias and Sagada, Mt. Province. IEC materials were also distributed as well as attending trade fairs were done. Chickpea seeds and different based food products were also sold.

\section{Results And Discussions}

\section{Activity 1. Product development of chickpea based food products Process in making chickpea flour}

Fully dried chickpea seeds of desi type variety ICCV 92955 was used. It has a milling recovery of $800 \mathrm{gm}$ per $1 \mathrm{~kg}$ of seeds. Dried seeds were sprinkled with water and oil, mix gently then it was sun dried for 3 to 5 days. Dried seeds was pass thru a dhal machine inorder to crush the dhal from the seed coat. Separate the seedcoat and dhal with the use of a winower or blower. The dhal was milled in a flour miller/ pulverizer. Sieved to separate the dhal and grits. Re-pulverized the grits inorder to produce a finer product. Chickpea flour is then pack and sealed in a container for future use. From the developed chickpea flour different products were formulated such as, oatmeal bar, tart, cracker, waffles, butter cookies and buns etc.

\section{Activity 2. Sensory evaluation of chickpea based food products developed}

Chickpea based food products which includes chickpea oatmeal bar, tart, cracker and buns were evaluated for its sensory characteristics. For chickpea oatmeal bars showed the best rating of like very much. Oatmeal bars with chickpea added was rated like moderately which was based on color, crunchiness, texture, and sweetness. This could maybe due to the rough texture of the chickpea flour.

Chickpea buns showed that the lower amount of chickpea flour the higher acceptability rating. Results showed that the lower the amount of chickpea flour added to the product the higher the acceptability rating. Lower rating was observed with the addition of chickpea flour, however found to be significantly acceptable by the panel members.Chickpea buns and crackers showed to have slight differences on the acceptability rating with the increase formulation of chickpea flour. This could be due to the fact that panel members are not used to the taste of a chickpea, since chickpea is a new food in our community.

Table 1. Sensory evaluation of chickpea based food products

\begin{tabular}{|l|l|l|}
\hline Product & Treatments & Sensory Evaluation Rating \\
\hline Chickpea Oatmeal bar & $\begin{array}{l}\text { T1: } 2 \text { cups all purpose flour: } 3 \text { cups quick cooking } \\
\text { oatmeal }\end{array}$ & 6.56 \\
\cline { 2 - 3 } & $\begin{array}{l}\text { T2: } 2 \text { cups all purpose flour: } 2 \text { cups quick cooking } \\
\text { oatmeal: } 1 \text { cup chickpea flour }\end{array}$ & 5.95 \\
\cline { 2 - 3 } & $\begin{array}{l}\text { T3:2 cups all purpose flour: } 1 \frac{1}{2} \text { cups quick } \\
\text { cooking oatmeal: } 1 \frac{1}{2} \text { cups chickpea flour }\end{array}$ & 6.31 \\
\hline & & \\
\hline
\end{tabular}




\begin{tabular}{|c|c|c|}
\hline Chickpea Tart & $\begin{array}{l}\mathrm{T}_{1} \text { Crust: } \\
11 / 2 \text { cups All-purpose Flour } \\
1 / 3 \text { cup butter } \\
1 / 4 \text { cup salt } \\
5 \text { tablespoon water } \\
\text { Filling: } \\
1 / 2 \text { cup mashed camote } \\
1 / 2 \text { cup mashed chickpea } \\
1 / 2 \text { cup condensed milk }\end{array}$ & 6.30 \\
\hline & $\begin{array}{l}\mathrm{T}_{2} \text { Crust: } \\
1 \text { cup All-purpose Flour } \\
1 / 2 \text { cup chickpea Flour } \\
1 / 2 \text { cup butter } \\
1 / 4 \text { cup salt } \\
5 \text { Tablespoon water } \\
\text { Filling: } \\
1 \text { cup mashed camote } \\
1 / 2 \text { cup condensed milk }\end{array}$ & 5.61 \\
\hline & $\begin{array}{l}\mathrm{T}_{3} \text { Crust: } \\
1 / 2 \text { cup All-purpose Flour } \\
1 / 2 \text { cup Chickpea Flour } \\
1 / 4 \text { cup butter } \\
1 / 4 \text { cup salt } \\
5 \text { Tablespoon water } \\
\text { Filling: } \\
1 \text { cup mashed Chickpea (Kabuli type) } \\
1 / 2 \text { cup Condensed Milk }\end{array}$ & 5.69 \\
\hline Cracker & $\begin{array}{l}\text { T1- 1c chickpea, } 1 \mathrm{c} \\
\text { all purpose flour, } 5 \mathrm{t} \text { salt, salt }\end{array}$ & 6.00 \\
\hline & $\begin{array}{l}\text { T2 - 1c chickpea,1c } \\
\text { all purpose flour, 5t salt, cheese powder }\end{array}$ & 5.50 \\
\hline & $\begin{array}{l}\text { T3 - 1c chickpea, 1c } \\
\text { all purpose flour, 5t salt, onion powder }\end{array}$ & 5.67 \\
\hline Buns & T1-170g All purpose Flour and 70 grams Chickpea & 4.47 \\
\hline & $\begin{array}{l}\text { T2-190g All purpose Flour and } 50 \text { grams Chickpea } \\
\text { flour }\end{array}$ & 5.07 \\
\hline & $\begin{array}{l}\text { T3- 220g All purpose Flour and } 20 \text { grams } \\
\text { Chickpea flour }\end{array}$ & 5.67 \\
\hline
\end{tabular}

\section{Activity 3. Nutritional analysis of chickpea flour as compared to rice/wheat flour}

Chickpea flour was analyzed at PIPAC and FNRI-DOST for its nutritional content, as per results it showed that it is high in dietary fiber, potassium, protein, iron and calcium. Dietary fiber is essential for a healthy diet. It is important for its ability to prevent ore relieve constipation, lower risk of diabetes, heart diseases, lower blood cholesterol, glucose levels and prevention of colon cancer. Chickpea was found to have three times dietary fiber than wheat and rice flour. Dietary fiber helps lower blood cholesterol level. According to Mayoclinic.com a diet high in fiber reduces blood pressure, lowers low density lipo protein or LDL. Chickpea helps prevent elevate blood sugar levels. It decreased triglyceride, cholesterol and LDL levels (www.livestrongcom/article/chickpea diet.

However using chickpea flour to supplement wheat flour is more nutritious than pure wheat flour according to, Annals 2006. Chickpea being rich in dietary fiber, both soluble and insoluble that may help reduce cholesterol levels. A study 2006, Annals of nutrition and metabolism found that serum and low density lipoprotein cholesterol levels were significantly lowered by chickpea supplement diet, compared with wheat supplement diet.

Potassium may help regulate blood pressure. People who get a lot of K in their diet have a lower risk of stroke. Increasing consumption foods rich in $\mathrm{K}$ may play a role in osteoporosis prevention. (University of Maryland medical center.umm.edu/altmed/articles/potassium000320.htm).

Proteins are involved in all cell functions. It is involved in structural support while others in bodily movement or in defense against germs. Hormonal proteins are messenger proteins w/c help coordinate certain activities. 
Iron $(\mathrm{Fe})$ is a trace mineral to the body. It helps in the formation of red blood cells and helps carry oxygen from the lungs to the body tissues. Calcium is needed for bones and teeth. Chickpea has significantly more calcium than wheat flour and rice. Glycemic index (GI) of chickpea is lower than wheat flour and milled rice. Low GI foods reduce blood sugar level thus preventing diabetes.

Table 2. Nutritional content of chickpea flour compared to wheat flour (All purpose flour) and rice flour

\begin{tabular}{|l|l|l|l|}
\hline $\begin{array}{l}\text { Nutrients Analyzed per } \\
100 \mathrm{gm}\end{array}$ & Rice flour & $\begin{array}{l}\text { Chickpea flour (ICCV- } \\
93954)\end{array}$ & $\begin{array}{l}\text { Wheat flour } \\
\text { (All purpose flour) }\end{array}$ \\
\hline Moisture, g & 10.2 & 8.3 & $9.8(13.2)$ \\
\hline Ash, g & 0.6 & 2.7 & $0.4(5.4)$ \\
\hline Energy, kcal & 358 & $358(356)$ & $377(455)$ \\
\hline Total fat, g & 0.3 & $10.4(0.6)$ & $3.6(1.2)$ \\
\hline Total Carbohydrate, g & 81.3 & $69.4(53.2)$ & $75.2(92.8)$ \\
\hline Dietary Fiber, g & 2.8 & $13.7(9.9)$ & $0.4(3.4)$ \\
\hline Protein, g & 7.4 & $19.2(20.6)$ & $11.0(12.4)$ \\
\hline Iron (Fe) mg & 1.0 & $12.0(4.5)$ & $4.1(5.8)$ \\
\hline Calcium & 27.0 & 129.0 & 82.0 \\
\hline Potassium, mg & 65 & 1,100 & 137 \\
\hline Glyceamic index & $60(\mathrm{~m})$ & $6($ low $)$ & $60(\mathrm{~m})$ \\
\hline
\end{tabular}

Analyzed by FNRI/ITDI-DOST, PIPAC 2012.Sourced: FNRI-DOST, 1997

\section{Activity 4. Nutritional Facts of Different Chickpea Based Food Products}

Food fortification is a critical way to ensure the world's most vulnerable populations receive essential micronutrients through food that $\mathrm{s}$ grown and consumed locally. Fortification is also one of the most cost effective ways to improve nutrition. The following tables shows the nutria facts of the different substituted chickpea based-food-products produce. The nutrient content of the different chickpea-based food products were computed using the 1997 Philippine Food Composition Table published by the Food and Nutrition Research Institute of the Department of Science and Technology.

The chickpea-based baked food products are good sources of nutrients particularly energy, fat, protein, carbohydrates, calcium and vitamin A. On a per serving basis, Chickpea Butter Cookies provides the most energy with 526 kcal. followed by Chickpea Oatmeal Raisin Cookies, 393 kcal., Chickpea Lengua, 376 kcal., and Chickpea Eggdrop Cookies with 371 kcal. Chickpea Oatmeal Bar has the least energy content with 105 $\mathrm{kcal}$ although the serving size differs from one product to another. Chickpea Butter Cookies has the most fat $(28.3 \mathrm{~g})$, protein $(9.5 \mathrm{~g}$, carbohydrates $(58.5 \mathrm{~g})$ and vitamin A (163.8 ug) content while Chickpea Eggdrop Cookies contains the most calcium (168.8) (Table 3.)

Table 3. Nutri facts of chickpea based food bakery products per serving.

\begin{tabular}{|l|l|l|l|l|l|l|}
\hline NUTRIENTS & $\begin{array}{l}\text { Chick } \\
\text { pea-Butter } \\
\text { Cookies } \\
(50 \mathrm{~g} / \\
\text { serving) }\end{array}$ & $\begin{array}{l}\text { Chickpea } \\
\text { Eggdrop } \\
\text { Cookies } \\
(80 \mathrm{~g} / \\
\text { serving) }\end{array}$ & $\begin{array}{l}\text { Chickpea } \\
\text { Lenguas } \\
(75 \mathrm{~g} / \\
\text { serving) }\end{array}$ & $\begin{array}{l}\text { Chickpea } \\
\text { Oatmeal Bar } \\
(29 \mathrm{~g} / \\
\text { serving) }\end{array}$ & $\begin{array}{l}\text { Chickpea } \\
\text { Camote } \\
\text { Hopia } \\
(47 \mathrm{~g} / \\
\text { serving) }\end{array}$ & $\begin{array}{l}\text { Chickpea } \\
\text { Raisin Cookie } \\
(75 \mathrm{~g} / \\
\text { serving) }\end{array}$ \\
\hline ENERGY (kcal) & 526 & 371 & 376 & 105 & 231 & 393 \\
\hline FAT $(\mathrm{g})$ & 28.3 & 3.9 & 19.1 & 7.3 & 10.7 & 18.7 \\
\hline PROTEIN (g) & 9.5 & 7.7 & 5.8 & 1.8 & 4.4 & 7.3 \\
\hline CHO (g) & 58.5 & 77.2 & 45.3 & 13.7 & 29.2 & 49.0 \\
\hline FIBER (g) & $(3.2)$ & $(2.6)$ & $(1.9)$ & $(0.9)$ & 1.3 & $(1.7)$ \\
\hline CALCIUM (mg) & 118.9 & 168.8 & 94.2 & 30.9 & 60.4 & 130.4 \\
\hline $\begin{array}{l}\text { VITAMIN A (ug } \\
\text { RE) }\end{array}$ & 163.8 & 0.2 & 88.7 & 25.6 & 38.1 & 103.1 \\
\hline
\end{tabular}

Nutrient content computed using the 1997 Philippine Food Composition Table

\section{Activity 5. Costing of chickpea based food products develop Production cost for chickpea flour}

Production cost and estimated return on cash expense of chickpea flour. Product costing was computed based on the prevailing market price. Production cost includes raw materials, fuel, electricity, packaging materials, labor and other expenses. Based on the flour yield of 19 boxes $(250 \mathrm{~g})$ the estimated production cost is $\mathrm{P} 89.46 / 250 \mathrm{gm} / \mathrm{box}$.

Table 4. Production cost for chickpea flour (Php)

\begin{tabular}{|l|l|l|l|}
\hline Ingredients & Quantity & unit cost & total cost (Php) \\
\hline chickpea seeds, kgs & $6 \mathrm{~kg}$ & 100 & 600.00 \\
\hline fuel \& electricity & 1 & 10.00 & 10.00 \\
\hline Packaging & 19 & 25 & 475.00 \\
\hline Total cost(Php)..... & & & $1,085.00$ \\
\hline
\end{tabular}




\begin{tabular}{|l|l|l|l|}
\hline other expenses(10\%) & & & 108.50 \\
\hline labor(hr) winnowing/cleaning & & & 468.75 \\
\hline milling/packing & & & 37.50 \\
\hline total production cost & & & $1,699.75$ \\
\hline yield/output (box 250g cap) & 19 & & \\
\hline production cost/pack & & & 89.46 \\
\hline
\end{tabular}

\section{Activity 6. Production cost of different chickpea based food products}

Production cost of the different products were computed/ estimated based on the prevailing market price.Chickpea products which includes oatmeal bar, tart, hot cross buns, cracker, lenguas and butter cake was computed for the return on cash expense (ROCE).The total production cost/expenses ranging from Php $70-240$ for the products mentioned above and with a yield ranging from 3 to 5 pieces depending on the products. The production cost per piece ranges from $3.69-52.78$ per piece. With a whole sale price ranging from 4.61-65.97 per piece. The return on cash expense is $25 \%$.

Table 5. Production cost of different chickpea based food products (Php)

\begin{tabular}{|l|l|l|l|l|l|}
\hline $\begin{array}{l}\text { Chickpea based food } \\
\text { product }\end{array}$ & Total cost (Php) & Yield (gm) & Cost (Php) & ROCE (\%) & $\begin{array}{l}\text { Whole sale } \\
(\text { Php })\end{array}$ \\
\hline Chickpea oatmeal bar & 260.00 & $65 / \mathrm{pc}$ & $3.69 / 30 \mathrm{~g}$ & $25 \%$ & 4.61 \\
\hline Chickpea tart & 92.33 & $19 / \mathrm{pc}$ & $4.84 / 30 \mathrm{~g}$ & $25 \%$ & 6.05 \\
\hline Cross Buns & 115.47 & $23 / \mathrm{pc}$ & $5.02 / 25 \mathrm{~g}$ & $25 \%$ & 6.27 \\
\hline Crackers & 70.23 & $9 / \mathrm{pc}$ & $7.80 / 30 \mathrm{~g}$ & $25 \%$ & 9.75 \\
\hline Lenguas & 158.35 & $3 / \mathrm{jar}$ & $52.78 / 16 \mathrm{~g}$ & $25 \%$ & 65.97 \\
\hline Butter cake & $24 / \mathrm{pc}$ & $9.79 / 45 \mathrm{~g}$ & $25 \%$ & 12.24 \\
\hline
\end{tabular}

\section{Activity 7. Conduct of trainings/IEC materials production/Product exhibition}

Inorder to promote a new crop, chickpea field day festival was conducted in April 9-12, 2013 in time with the harvesting. Training was conducted on the production and processing of chickpea based food products. Fourty five (45) participants from the different barangays mostly women attended in Sagada while ninety eight (98) attendees participated in Loo, Buguias. Different attendees were represented by the different barangays namely; Bangao, Amgaleygey, Abatan, Poblacion, Sebang and Loo, Buguias. Based on specialization lectures were discussed/ and presented such as; chickpea crop production, pest management, nutritional benefits and processing. After the lectures participants were given the opportunity to harvest the chickpea in the field. In the afternoon participants had a hands on training on processing chickpea based food products such as crackers, pulvoron, leche flan, chickpea vegetable salad. Two hundred sets of leaflets on chickpea production and processing were distributed to the participants during the field day in Sagada, Mt. Province and Loo, Buguias, Benguet from April 9-12, 2013.

\section{Conclusion}

Chickpea based food products showed to have slight differences on the acceptability rating with the increase formulation of chickpea flour. This could be due to the fact that panel members are not used to the taste of a chickpea, since chickpea is a new food in our community. Thirty percent (30\%) chickpea substitution showed acceptable products.

It is therefore concluded that chickpea flours is more nutritious than wheat flour because of it is high in dietary fiber, protein, calcium, potassium, folate and with low glycemic index

Return on cost expenses of the different chickpea substituted products had 25\% for oatmeal bar, tart, buns, crackers, lenguas and butter cake.

Trainings was conducted with 284 participants from Benguet, Mt. Province and Nueva Vizcaya with more or least 400 IEC materials on production and processing aspect of chickpea were distributed during the training and trade fair exhibitions.

IEC materials/Publications includes, Package of technology for chickpea production in CAR, Chickpea recipes, chickpea varieties for the Cordillera region, medicinal and nutritional value of chickpea. Likewise, paper presentations in regional, national and international conferences were participated inorder to promote the technology as well.

\section{Acknowledgement}

The authors would like to express their sincere gratitude to the different funding agencies; Department of Agriculture-Bureau of Agricultural Research Agri-Pinoy, Department of Agriculture-CAR Regional Office Unit, PCARRD-DOST, PCIEERD-DOST, ICRISAT; Local Government Unit of Buguias, Sagada, Bokod, to the NPRCRTC staffs; Donita Simongo, Teresita Masangcay, Joyce Mama-o, Viona Gano, Fernando Balog-as, Loliven Benito, Macaria Carpio. To the Benguet State University administrative staffs; President, Vice 
President for Research \& Extension, Office of Research \& Extension and the different administrative staffs of Benguet State University and others who was not mentioned. We thank them all without their cooperation this project was not a success.

\section{References}

[1]. Gonzales, F.R, et al 2010. Package of Technology of chickpea (Cicer arietanum L.) in Cordillera Administrative Region (CAR). Benguet State University, La Trinidad, Benguet

[2]. Gonzales, I. C., H. L. Qunidara, ET. Botangen. 2009. Development of chickpea based food products. Benguet State University, La Trinidad, Benguet

[3]. FNRI-DOST. 1997. The Philippine Food Composition. FNRI-DOST, Bicutan, Taguig, Metro Manila.

[4]. www.livestrong.com/article/chickpea.diet

[5]. Food references.com.

[6]. FNRI-DOST. 2009. Glyceamic index of common foods. FNRI-DOST, Taguig, Metro Manila 